UDC- 811.111

https://doi.org/10.31548/philolog2021.03.026

\title{
SOME VOWEL CHANGES IN RECEIVED PRONUNCIATION
}

\author{
P. F. JAFAROVA, Senior Lecturer, \\ Azerbaijan University of Languages \\ E-mail: jafarova.parvana@yahoo.com \\ https://orcid.org/0000-0002-4747-5711
}

\begin{abstract}
English is a global language which is being taught all over the world. In Britain Received Pronunciation is adopted as a model for foreign language teaching, although very few people speak it. When teaching English as a foreign language, it is impossible to teach students different variants or dialects. There is only one pronunciation model that students can learn, that is Received Pronunciation (RP). The article deals with some vowel changes that happened recently in Received Pronunciation (RP), namely fronting of / $\mathrm{u}:$ / and / $\mathrm{v} /$ vowels, the shift of vowels / æ/ into / a /, / e / into / $/ /$, / aI / into / /II/, the tendency of diphthongs to be pronounced as long vowels and HAPPY-tensing. These tendencies have become well-established and are widely used by young and middle aged generations. So, most dictionaries have already accepted these changes and new symbols are being used.The aim of this research is to explore aspects of these changes. Here we talked about some new tendencies in the vowel inventory of Recieved Pronunciation. These tendencies were changes in the quantity and quality of cardinal vowels. We have also witnessed tectonic changes in the simbolic system of the English vowels. There is also emprical basis of the research which analyses the speech of different speakers taken from BBC. Interstingly, these new changes are not being taken into account in EFL classes very well, despite the fact that RP is the best accent to teach to foreign students. The traditional symbols which are widely used today are a phonetic reflection of an older version of the prestigious British pronunciation. It can be assumed that there is no need to change the simple and traditional variant that reflects the phonetic reality. However, the time has come for a fundamental change in the symbolic system of English vowels. The change of / $æ /$ to / a / in the word TRAP has already been accepted by a number of authors. The change from / $\mathrm{e} /$ to $/ \varepsilon /$ in the word DRESS was made by C. Upton [10] and supported by J.Wells [12]. Harrington J. also suggests the symbol / $\varepsilon j /$ in the word FACE [7]. In this article we conclude that English like other languages adapts to changing conditions and is constantly developing. The results of theoretical research help to determine its development tendency.
\end{abstract}

Keywords: Received Pronunciation, vowel change, diphthongs, monophthongs, lexical set, symbols.

Introduction. Our language adapts to changing circumstances. It changes constantly and slowly. While observing we understand its flow and development. Periodic observations can even tell us about any changes that will take place in the upcoming centuries. This study includes certain pronunciation changes in the modern English language Vowel System over the past 50 years.

An adjusted version of the modern and standard pronunciation that people hear in real life is Received Pronunciation. Some linguistics think that there is no point to learn an accent that dates back to the 18th century and is almost never used today. Therefore, some books, textbooks and dictionaries still use the traditional norm and do not pay attention to the phonetic changes. J. Przedlacka claims that textbooks are practically obsolete $[9$, p. 35]. However, language learning begins with correct pronunciation. In order to prove one should consider the sixth edition of the Oxford Advanced Learner's dictionary (2001). In this dictionary the transcription of the words like trap, price, or square 'square' is based on the traditional forms /træp /, /praıs /, /skweə /. However, C. Upton shows that the pronunciation of these words has changed and become / trap /, /prAIs /, /skwe: / [10, p. 23]. The dictionary dates back to the year of 2000 and it does not reflect an updated version of the standard pronunciation.

Meanwhile, English is taught and spoken in every part of the world as both a second language and a foreign language. Therefore, this language has a global status. Although only $3 \%$ of people speak Received Pronunciation, this accent is widely used in foreign language teaching. As language is constantly evolving and changing, Received Pronunciation should also benefit from these innovations and be taken into account in the teaching of a foreign language.

If we look into the vowel system of Received Pronunciation, we will witness a great change in the realization of vowel phonemes since D. Jones [8]. The main changes are quantitative and qualitative changes of the cardinal vowels. We will also come across new symbols accepted and used by different linguists.

Recent researches and publications. The study of alternations was one of the most important conviction of Baudouin de Courtenay and he suggested that linguists should work with living languages. In Modern English U.Altendorf, L. Bauer, 
A. Fabricius, C. Upton, J. Wells, J. Wikstrom, and other linguists have extensively studied new tendencies in the vowel system of RP [1], [2], [5], [10], [11], [13]. Research of new tendencies is of great importance both from a purely scientific and educational point of view.

The purpose. Correct pronunciation is one of the most important issues while learning a new language. Received Pronunciation was created to maintain the standardization and it became a symbol of education. This accent is spoken in a small part of Britain, but it is considered to be the best accent of British English. So our main aim is to explore phonetic tendencies in RP. It is a very difficult process to talk about new tendencies. It is not right to speculate about the end by seeing the beginning of change or to say that the process will continue. The main reason for these changes is the fact that language is constantly developing and new tendencies are emerging. It is upon linguists to identify and investigate these changes. In this article we try to identify vowel changes that happened in Received Pronunciation. In order to meet our objectives an experiment was carried out as well.

Data and methods. In order to carry out an experiment effectively the material should be chosen carefully. For this purpose, we have selected 70 words from the speeches of the BBC newsreaders, the members of Royal family and British officials. 44 words were involved in the experiment. All the words we have chosen are two-, three- and four-vowel words. The experiment was carried out on the basis of the computer program "Praat". The results of the experiment have been compared with the theoretical outcomes and illustrated in the article.

Results. If we look into the vowel system of C. Upton's Received Pronunciation, we will witness a great change in the realization of vowel phonemes. The main changes are quantitative and qualitative change of the cardinal vowels. There are also new vowels in its system. In order to show their correct symbols $C$. Upton used new symbols [10, p. 24].

$|æ|>\mid$ a $/$. In our experiment in the words planet, have, baton, platform, strategy, ambassador the vowel / æ/ is pronounced more openly / a /. Although this pronunciation is specific to the northern dialect, it is articulated like that in $\mathrm{RP}$, as well as in the southern dialects. The use of more open vowel differs RP from American English, where / æ / is found and is pronounced longer, more closed and sometimes as a diphthong. Our experiment proves that the pronunciation of the vowels in the above given words is the same as the comments of $A$. Cruttenden, C. Upton taking / a / as a symbol [4], [10]. In our opinion, the transition of / æ / to / a / is the most noticeable vowel change in recent years and should be taken into account while teaching of English as a Foreign Language.

For example: / $\mathrm{p}$ I a $\mathrm{n}$ I $\mathrm{t} / \mathrm{a}$ ) oscillogram b) spectrogram
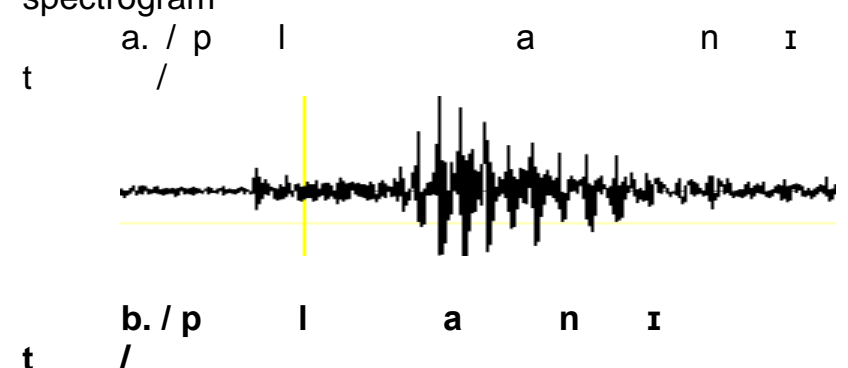

$\mathbf{t}$

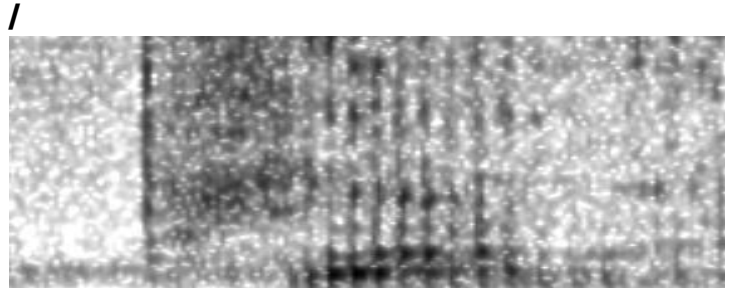

As we know, monophthongisation is the process which a diphthong becomes a monophthong. In the words belonging to CURE lexical set we witness the long pronunciation of the diphthong / ชə / as / 0 : /. This tendency is given in the Oxford Dictionary (2001) along with the traditional pronunciation form. The results of our experiment of the words cure, sure, ensure, poor coincide with the theory of phonetics such as A. Cruttenden, B.Hannisdal, C. Upton, J. Wells that the diphthong / $\mho_{\partial} /$ is widely replaced by the long /o:/ [4], [6], [10], [12].

For example : ensure /I n ' $\int \mathrm{o:/}$ a) oscillogram b) spectrogram

a) /I n ' 5 o: /

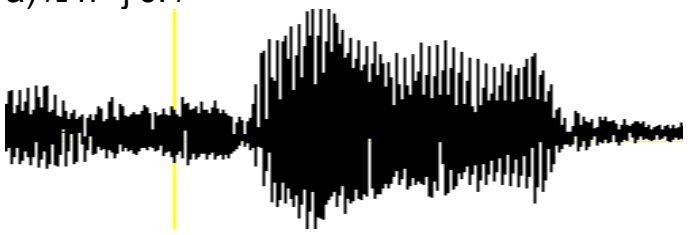

b) /I n ' J o: /

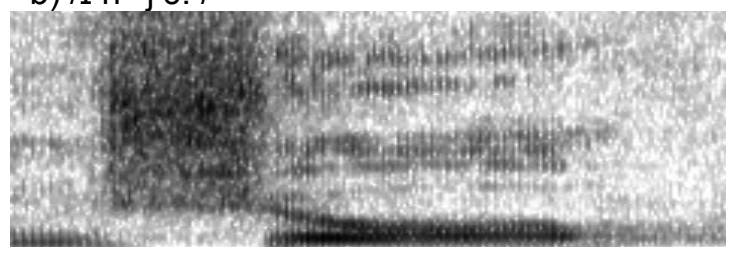

The other general trendency of RP is to lower the articulation of short front vowels. The change from / e / to / $\varepsilon$ / in the words comment and strengthen has been extensively studied by C. Upton, and B. Hannisdal supports his opinion $[6$, p. 56]. Our experimental phonetic analysis confirms this tendency.

$$
/ \text { 's } \operatorname{tr} \varepsilon \eta \theta \partial n / \text { a) oscillogram b) }
$$
spectrogram
ə $\mathrm{n} /$ 


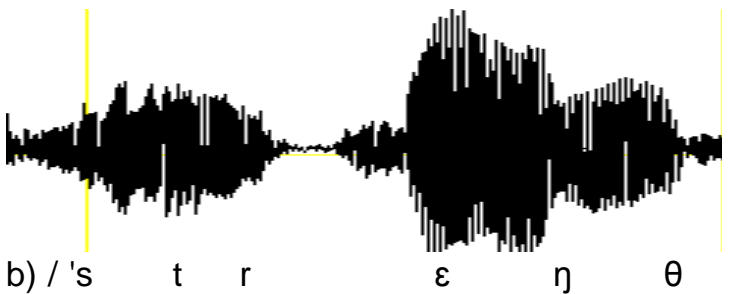

ə
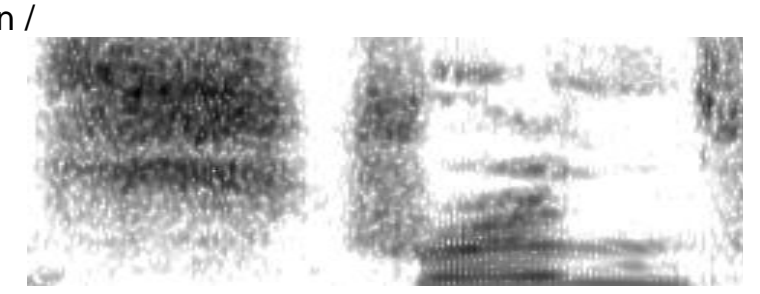

The comparative study of formants of diphthongs are somehow excluded. However, A. Cruttenden tried to measure the formant value of diphthongs [4, p. 105]. In the word GOAT the diphthong / $\partial v$ / is pronounced in the back and /əu| in the front. B. Collins and I. Mees show only the variant / ov /, but they note that the youth tend to pronounce it in the front [3, p. 107]. Our experimental phonetic analysis shows that the younger speakers of RP tend to pronounce the diphthong in the words promote, flow, local, global, growth, goal in the front position.

For example : /g $r$ ə 0 $\theta /$ a) oscillogram b) spectrogram

a) $/ g r \quad$ ə $\quad v$

$\theta$

1

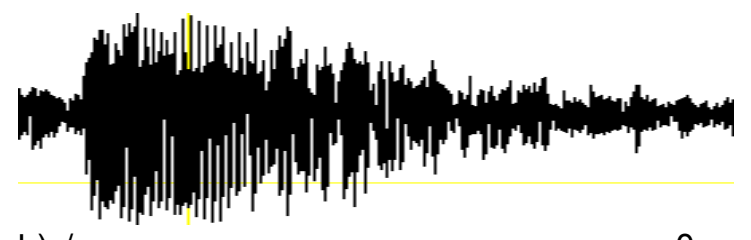

b) / $g$

ə

u

$\theta$

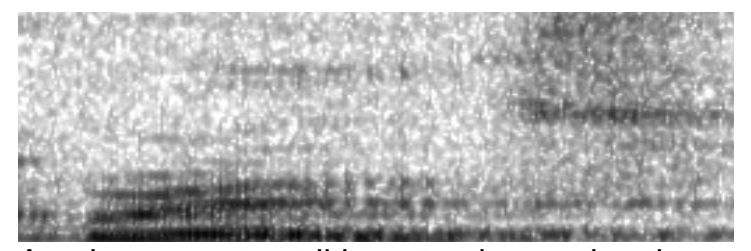

Another most striking tendency is the tensing of the unstressed final $/ \mathrm{l} /$. This is also known as HAPPY-tensing. Before in the words like happy and coffee the final vowel used to be pronounced with $/ \mathrm{l} /$, while nowadays it is pronounced with /i/. A.Cruttenden, J. Wellls note that this is a well-developed change in RP [4], [11]. During the experimental analysis of the words reality, very happy, city, we have observed the Happy-tensing tendency clearly.

For example: /s i t i/ a) oscillogram b) spectrogram
a) / $\mathrm{s}$
I
$\mathrm{t}$

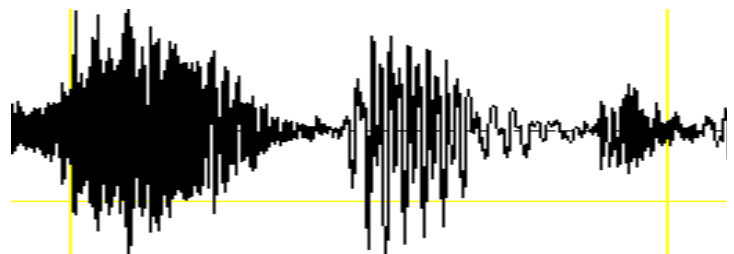

b) / $\mathrm{s}$

I

$\mathrm{t}$

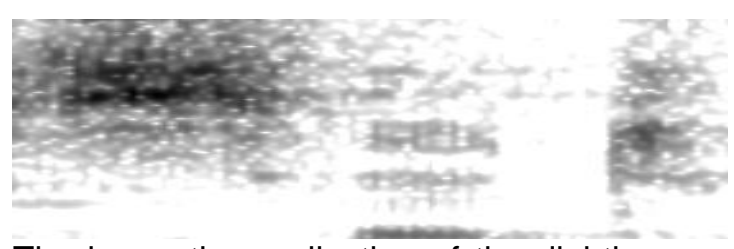

The innovative realization of the diphthong in the words like mind, price, nice, horizon has shifted its open centralized front position/al/ to half-open centralized back pronunciation $/ \wedge \mathrm{I} /$. A. Cruttenden accepted the new realization of the diphthong [4, p. 194] and C. Upton indicated a new symbol which best describes the real sound today [10, p. 19]. The Oxford English Dictionary shows the pronunciation of these words with / $\mathrm{\Lambda} /$.

For example: / 'm $\wedge$ I n d / a) oscillogram b) spectrogram
a) / 'm
$\mathbf{I}$
n $\quad$ d

l

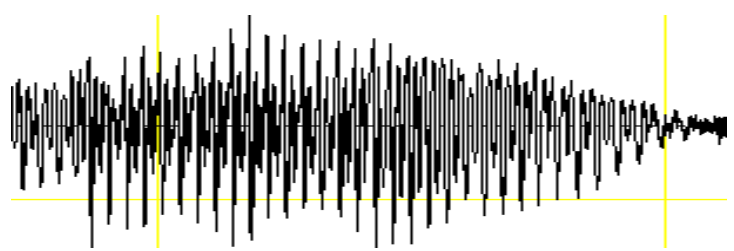

b) / 'm

I

n

d

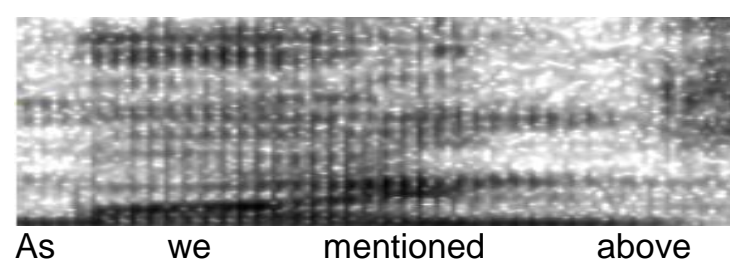

monophthongisation is a new tendency and to pronounce centering diphthongs as monophthongs has been widespread. Many linguists have already accepted that the words belonging to SQUARE lexical set the vosel is a monophthong $/ \varepsilon: /$. We have experimented the words compare, fairly, bare and our analysis coincided with the fact that pronunciation with the leə/ is old fashioned and actually, they are pronounced with $/ \varepsilon: /$.

For example: / 'f $\varepsilon$ : I i/ a) oscillogram b) spectrogram
a) / ' f
$\varepsilon:$

i/ 

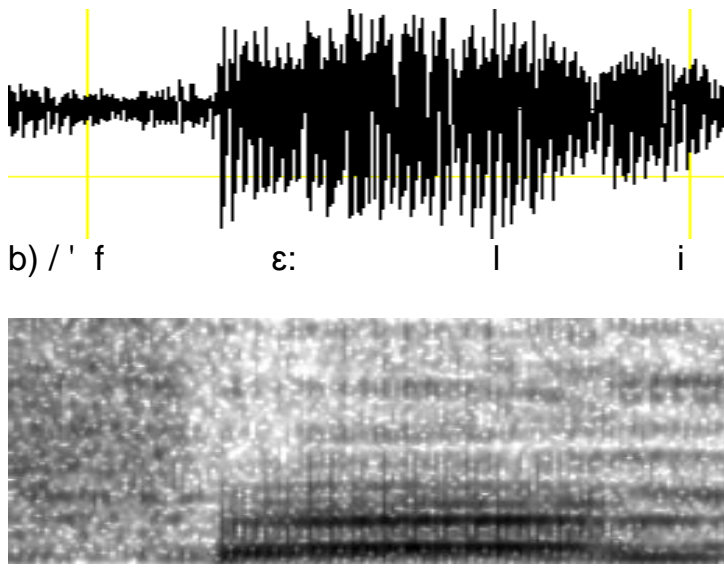

The vowel/ u: /in the words like goose, mood, fruit tended to be pronounced as a long back vowel in the twentieth century. At present the quality of the vowel /u:/ ha shifted. This phenomenon is known as GOOSE-fronting which is common among the younger RP speakers. Collins and Mees A., Cruttenden, J.Wells, remark this phenomenon very striking [3], [4], [11]. Harrington even observed it in the speech of the Queen Elizabeth II [7, p. 126]. We have also included some words to identify /u:/-fronting in the $\mathrm{RP}$ speakers. The results were very interesting after the sounds $/ \mathrm{j}, \int, \mathrm{t} /$.

For example: /k $\boldsymbol{\theta}^{\prime} \mathbf{m}$ j $\boldsymbol{y} \mathbf{n}$ I $\mathbf{t}$ I $\mathbf{z} /$ a) oscillogram b) spectrogram

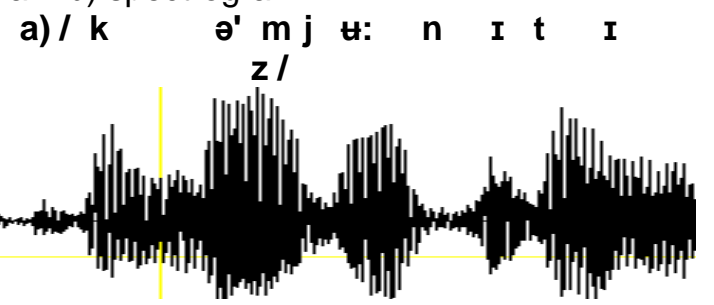

Refernces

1. Altendorf, U., \& Watt, D. (2008) The Dialects in the South of England: Phonology. In B.Kortman, \&C. Upton (Eds.), Varieties of English : The British Isles Mouton de Gruyter, 194-222

2. Bauer, L. (1994). Watching English change: An Introduction to the study of linguistic change in standard Englishes in the $20^{\text {th }}$ century. London: Longman 216

3. Collins, B., Mees I. M. (2013) Practical Phonetics and Phonology. A resource book for students, $3^{\text {rd }}$ edition. London: Routledge, 354.

4. Cruttenden, A., Gimson, A. C (2008) Gimson's Pronunciation of English. $6^{\text {th }}$ edition. London: Hodder Education, 408.

5. Fabricius, A. (2002) Ongoing Change in modern RP: Evidence for the disappearing stigma of t-glottaling. English World-Wide 23, (1), 115136

6. Hannisdal, B. R. (2006) Variability and Change in Received Pronunciation- $A$ study of six phonological variables in the speech of television

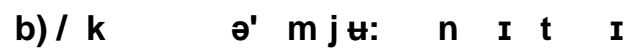
$\mathbf{z} /$

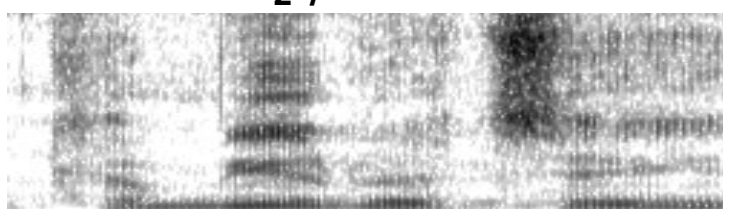

Discussion. Generally, it is a very difficult process to talk about new tendencies. The main reason for these changes is the fact that language is developing and new tendencies are inevitable. The traditional symbols widely used today are a phonetic reflection of an older version of the British English pronunciation. It can be assumed that there is no need to change the simple and traditional variant that reflects the phonetic reality . However, the time has come for a fundamental change in the symbolic system of English vowels. Therefore this work aimed to study the patterning of new tendencies in vowel system of the English Language. Thanks to the experimental analysis we could confirm some sound changes that have happened recently.

Conclusions and prospects. Overall, this article has tried to deal with an updated description of Recieved Pronunciation considering some vowel trends. By the help of experiments we could answer some research questions and confirm them. This research will allow the teachers and students of EFL classes to pay attention to the latest innovations and take them into account while teaching or learning the English language, as the social importance of good pronunciation has always been present in Britain for centuries.

newsreaders. PHD dissertation, University of Bergen, 271.

7. Harrington, J. (2007) Evidence for a relationship between synchronic variability and diachronic change in the Queen's annual Christmas broadcasts. In J.Cole \& J.Hualde Mouton de Gruyter (Eds), Laboratory Phonology (9), 125-143.

8. Jones, D. (1962) An Outline of English Phonetics, $9^{\text {th }}$ edition. Cambridge, 246.

9. Przedlacka, J. (2001) Estuary English and RP: Some recent findings. Sudia Anglica Posnaniensia (36), 35-50.

10.Upton, C. Received Pronunciation. In $C$. Upton \& B. Kortmann (Eds.) Varieties of English: The British Isles: 237-252.

11.Wells, J. C. (1990) A phonetic update on RP. In Moderna Sprak, 82: 3-9.

12. Wells, J. C. (2000) British English Pronunciation Preferences: A Changing Scene. Journal of the International Phonetic Association. 29(1), 33-55. 
13.Wikstrom, J. (2013) An acoustic study of the RP English LOT and Thought vowels. Journal of the International Phonetic Association Vol.43, No. 1 Cambridge University Press, 37-47.

\section{ДЕЯКІ ЗМІНИ ГОЛОСНИХ У ОТРИМАНІЙ ВИМОВІ П. Ф. Джафарова}

Анотація. Англійська мова - глобальна мова, яку викладають у всьому світі. у Британії отримана вимова прийнята як модель викладання іноземних мов, хоча дуже мало людей розмовляє нею. Викладаючи англійську мову як іноземну, неможливо навчити учнів різних варіантів чи діалектів. Існує лище одна модель вимови, яку студенти можуть вивчити, це Отримана вимова $(R P)$. Стаття присвячена деяким змінам голосних, які нещодавно відбулися в одержаній вимові (RP), а саме фрронт / и: / та / v / голосних, зміщення голосних / æ / у / a /, / e / into / ع / / aI / into / $\wedge$ I, тенденція дифттонгів вимовлятись як довгі голосні та ЩАСЛИВЕ напруження. Ці тенденції стали добре усталеними та широко використовуються поколіннями молодого та середнього віку. Отже, більшість словників вже прийняли ці зміни, і використовуються нові символи. Метою цього дослідження є вивчення аспектів цих змін. Тут ми говорили про деякі нові тенденції в інвентаризації голосних вимовленої вимови. Ці тенденції полягали у зміні кількості та якості основних голосних. Ми також спостерігали тектонічні зміни в символічній системі англійських голосних. Існує також емпірична основа дослідження, яке аналізує мовлення різних ораторів, взяте з ВВС. Цікаво, що ці нові зміни не враховуються дуже добре на уроках $E F L$, незважаючи на те, що RP є найкращим акцентом для навчання іноземних студентів. Традиційні символи, які широко використовуються сьогодні, $є$ фоонетичним відображенням старої версії престижної британської вимови. Можна припустити, що немає потреби змінювати простий і традиційний варіант, що відображає фонетичну реальність. Однак настав час кардинальної зміни символічної системи англійських голосних. Зміна / æ / на / а / у слові TRAP вже прийнята багатьма авторами. Зміна / е / на / $\varepsilon$ / у слові DRESS було зроблено К. Аптоном [10] та підтримано Дж. Уеллсом [12]. Дж. Гаррінгтон також пропонує символ / عj / у слові FACE [7]. У цій статmі ми дійшли висновку, що англійська, як і інші мови, адаптується до мінливих умов і постійно розвивається. Результати теоретичних досліджень допомагають визначити тенденцію його розвитку.

Ключові слова: отримана вимова, зміна голосних, дифртонги, монофртонаи, лексичний набір, символи. 